\title{
Randomized controlled clinical trial comparing implant sites augmented with a volume-stable collagen matrix or an autogenous connective tissue graft: 3-year data after insertion of reconstructions
}

\author{
Thoma, Daniel S ; Gasser, Thomas J W ; Jung, Ronald E ; Hämmerle, Christoph H F
}

\begin{abstract}
AIM To assess mid-term clinical, radiographic and profilometric outcomes at implant sites, previously grafted with a volume-stable collagen matrix (VCMX) or an autogenous subepithelial connective tissue graft (SCTG). METHODS VCMX or SCTG were randomly applied to single implant sites in 20 patients. Following abutment connection and insertion of final reconstructions (baseline), patients were re-examined at 6 months $(6 \mathrm{M})$, at 1 year (FU-1) and at 3 years (FU-3). Measurements included the following: clinical data, radiographic measurement of first bone to implant contact (fBIC), soft tissue thickness and volumetric outcomes. Non-parametric tests and estimates were applied for the statistical analysis. RESULTS The median buccal mucosal thickness increased by $0.5 \mathrm{~mm}$ (Q1: -0.5; Q3: 1.25) $(\mathrm{VCMX})(\mathrm{p}=.281)$ and by $0.8 \mathrm{~mm}(\mathrm{Q} 1: 0.0 ; \mathrm{Q} 3: 2.5)$ (SCTG) $(\mathrm{p}=.047)$ between BL and FU-3 (intergroup $\mathrm{p}=.303$ ). The profilometric changes of the buccal soft tissues demonstrated a median decrease between BL and FU-3 of $-0.2 \mathrm{~mm}$ (Q1: -0.5; Q3: -0.1) ( $\mathrm{p}=.039)$ for VCMX and a decrease of $-0.1 \mathrm{~mm}(\mathrm{Q} 1:-0.8$; Q3: 0.1) ( $\mathrm{p}=.020)$ for SCTG, respectively (intergroup $\mathrm{p}=.596$ ). Peri-implant soft tissues and bone levels remained healthy throughout the entire study period. PROMs did not show any significant differences between the groups nor significant changes over time. CONCLUSION Minimal changes of the peri-implant tissue contour as well as of the soft tissue thickness were observed at implant sites previously grafted with VCMX or SCTG.
\end{abstract}

DOI: https://doi.org/10.1111/jcpe.13271

Posted at the Zurich Open Repository and Archive, University of Zurich

ZORA URL: https://doi.org/10.5167/uzh-187813

Journal Article

Accepted Version

Originally published at:

Thoma, Daniel S; Gasser, Thomas J W; Jung, Ronald E; Hämmerle, Christoph H F (2020). Randomized controlled clinical trial comparing implant sites augmented with a volume-stable collagen matrix or an autogenous connective tissue graft: 3-year data after insertion of reconstructions. Journal of Clinical Periodontology, 47(5):630-639.

DOI: https://doi.org/10.1111/jcpe.13271 
DR. DANIEL STEFAN THOMA (Orcid ID : 0000-0002-1764-7447)

Article type : Original Article Clinical Periodontology

RANDOMIZED CONTROLLED CLINICAL TRIAL COMPARING IMPLANT SITES AUGMENTED WITH A VOLUME-STABLE COLLAGEN MATRIX OR AN AUTOGENOUS CONNECTIVE TISSUE GRAFT: 3-YEAR DATA AFTER INSERTION OF RECONSTRUCTIONS

Daniel S. Thoma ${ }^{1}$, Thomas J. W. Gasser ${ }^{1}$, Ronald E. Jung ${ }^{1}$, Christoph H. F. Hämmerle ${ }^{1}$

Running title: volume stability of implant sites

Key words: soft tissue augmentation, soft tissue volume, collagen-based matrix, subepithelial connective tissue graft, dental implant

1 Clinic of Reconstructive Dentistry, Center of Dental Medicine, University of Zurich, Switzerland

Address for correspondence:

PD Dr. med dent. Daniel S. Thoma

Clinic of Reconstructive Dentistry

Center of Dental Medicine, University of Zurich

Plattenstrasse 11, $\mathrm{CH}-8032$ Zurich, Switzerland

Phone: +41446343260

Fax: +41446344305

e-mail: daniel.thoma@zzm.uzh.ch

This article has been accepted for publication and undergone full peer review but has not been through the copyediting, typesetting, pagination and proofreading process, which may lead to differences between this version and the Version of Record. Please cite this article as doi: $\underline{10.1111 / \mathrm{JCPE} .13271}$

This article is protected by copyright. All rights reserved 


\section{CONFLICT OF INTEREST AND SOURCE OF FUNDING STATEMENT}

The study was funded by Geistlich Pharma AG, Wolhusen, Switzerland and by the Clinic of Reconstructive Dentistry, Center of Dental Medicine, University of Zurich, Switzerland. Dres. Hämmerle, Jung \& Thoma received lecture fees and research support from Geistlich Pharma AG. No conflict of interest is reported related to the outcomes of the study.

This article is protected by copyright. All rights reserved 


\section{Clinical Relevance}

Scientific rationale for the study: Soft grafting procedures to augment mucosal thickness are often performed at implant sites to enhance esthetics and peri-implant health. Limited midterm data following crown insertion is available for implant sites having been grafted with autogenous grafts (SCTG) or a volume-stable collagen matrix (VCMX).

Principal findings: Implant sites grafted with VCMXs or SCTGs demonstrated minimal changes of the buccal tissue volume, stable marginal bone levels and peri-implant health 3 years after insertion of final reconstructions without relevant differences between the two groups.

Practical implications: After insertion of final reconstructions, implant sites previously augmented with VCMXs or SCTGs rendered stable outcomes after a follow-up time of 3 years.

This article is protected by copyright. All rights reserved 


\section{ABSTRACT}

Aim: To assess mid-term clinical, radiographic and profilometric outcomes at implant sites, previously grafted with a volume-stable collagen matrix (VCMX) or an autogenous subepithelial connective tissue graft (SCTG).

Methods: VCMX or SCTG were randomly applied to single implant sites in 20 patients. Following abutment connection and insertion of final reconstructions (baseline), patients were re-examined at 6 months (6M), at 1 year (FU-1) and at 3 years (FU-3). Measurements included: clinical data, radiographic measurement of first bone to implant contact (fBIC), soft tissue thickness and volumetric outcomes. Nonparametric tests and estimates were applied for the statistical analysis.

Results: The median buccal mucosal thickness decreased by $-0.5 \mathrm{~mm}$ (Q1:0.5;Q3:$1.25)(\operatorname{VCMX})(p=0.281)$ and by $-0.75 \mathrm{~mm}(\mathrm{Q} 1: 0.0 ; \mathrm{Q} 3:-2.5)(\mathrm{SCTG})(\mathrm{p}=0.047)$ between $B L$ and FU-3 (intergroup $p=0.303$ ). The profilometric changes of the buccal soft tissues demonstrated a median decrease between $\mathrm{BL}$ and $\mathrm{FU}-3$ of $-0.2 \mathrm{~mm}$ (Q1:-0.5;Q3:$0.1)(p=0.039)$ for VCMX and a decrease of $-0.1 \mathrm{~mm}(\mathrm{Q} 1:-0.8 ; Q 3: 0.1)(p=0.020)$ for SCTG respectively (intergroup $p=0.596)$. Peri-implant soft tissues and bone levels remained healthy throughout the entire study period. PROMs did not show any significant differences between the groups nor significant changes over time.

Conclusion: Minimal changes of the peri-implant tissue contour as well as of the soft tissue thickness were observed at implant sites previously grafted with VCMX or SCTG.

This article is protected by copyright. All rights reserved 


\section{INTRODUCTION}

Soft tissue augmentation therapy is indicated in partially and fully edentulous patients to increase the mucosal/gingival thickness around dental implants and teeth in conjunction with dental reconstructions (Schneider et al., 2011). These procedures applying autogenous subepithelial connective tissue grafts (SCTG) represent the current gold standard to surgically correct localized alveolar defects as pre-prosthetic site development and to enhance biological and esthetic outcomes at implant sites (Thoma et al., 2009, Thoma et al., 2014, Sculean et al., 2019, Roccuzzo et al., 2017, Bouri et al., 2008, Thoma et al., 2018, Giannobile et al., 2018).

Research has focused on the development and preclinical as well as clinical assessment of various soft tissue substitutes serving as replacements for autogenous grafts (Thoma et al., 2010, Lorenzo et al., 2012, Zeltner et al., 2017, Thoma et al., 2016). This is based on the fact that the use of soft tissue substitutes results in a reduced patient morbidity and a shorter surgery time. A plethora of materials was evaluated in the past 20 years, predominantly of allogenic or xenogeneic origin (Wolff et al., 2016). Gain in mucosal or gingival thickness, applying these soft tissue substitutes, appears to be challenging to obtain as well as to maintain. More recently, a volume-stable collagen matrix (VCMX) rendered a volume gain non-inferior to SCTGs at implant sites as assessed by transmucosal probing and profilometric outcomes (Zeltner et al., 2017). The outcomes of the study are limited by the fact that the observation period represented the initial healing phase of 3 months postsurgery. Thereafter, abutment connection was performed, followed by the placement of final implant-borne reconstructions. This resulted in a number of confounding factors associated with varying diameters and shapes of healing abutments as well as differences in terms of the emergence profile between the sites. No mid-term data for soft tissue substitutes having been applied at implant sites were reported so far.

The aim of the present study was, therefore, to assess clinical, radiographic and profilometric outcomes of implant sites previously treated with VCMX or a SCTG 3 years after insertion of final reconstructions.

\section{Material ANd Methods}

\section{STUDY DESIGN}

The present study was designed as a non-interventional follow-up of patients previously enrolled in a randomized controlled clinical study performed according to ISO Standard 14155:2011, Clinical Investigation of medical devices for human patients with appendices VIII and $X$ of the Medical Device Directive 93/42EFC and Declaration of Helsinki, 2004 (Thoma et al., 2016). The study was approved by the local ethics committee (KEK_ZH-Nr 
2012-0226) and performed at the Clinic of Reconstructive Dentistry in Zürich between November 2015 and March 2018. The reporting of the present study follows the guidelines of the CONSORT statement (http://www.consort-statement.org/).

\section{INCLUSION CRITERIA}

Specific inclusion criteria involved:

1. Patients previously enrolled in an RCT (Thoma et al., 2016) and a follow-up study (Huber et al., 2018) were re-examined three years post insertion of final reconstructions.

2. Final restoration inserted at the implant site

3. Ability to fully understand the nature of the proposed non-interventional long-term followup study and the ability to sign the informed consent form

\section{EXCLUSION CRITERIA:}

1. Newly developed disease interfering with soft tissue regeneration (e.g. diabetes)

2. Peri-implant infection (not related to previously performed soft tissue regeneration) following the insertion of the final reconstruction

3. Second soft tissue augmentation since completion of study (Thoma et al., 2016)

4. Severe trauma to implant site

5. Orthodontic treatment in the same quadrant

6. Patients not willing to participate in the 3-year follow-up examination.

\section{Clinical Procedures}

In all 20 patients originally included in a RCT (Thoma et al., 2016) a soft tissue grafting procedure was performed at a single-tooth implant site (submerged healing). In brief, following local anaesthesia, sulcular incision was made around the neighbouring teeth of a single tooth gap. Subsequently, a straight crestal or slightly palatal/lingual horizontal incision was performed to connect the mesial and distal line angles. A split-thickness flap was elevated on the buccal side. A pouch was then prepared exceeding the space needed for the transplant. Thereafter, a sealed envelope was opened, containing the assignment for either one of two treatment modalities:

- cross-linked volume-stable collagen matrix (VCMX) (Geistlich Fibro-Gide ${ }^{\circledR}$, Geistlich Pharma AG, Wolhusen, Switzerland)

- autogenous subepithelial connective tissue graft (SCTG).

In group VCMX, the matrix with an initial dimension of $25 \mathrm{~mm} \times 25 \mathrm{~mm} \times 8 \mathrm{~mm}$ was shaped according to the needs at the recipient site (desired volume).

This article is protected by copyright. All rights reserved 
In group SCTG, following a single incision technique, an autogenous connective tissue graft was harvested at the palate.

The graft was positioned into the pouch and sutured to the palatal flap. Primary tension-free wound closure was obtained with a horizontal mattress and single interrupted sutures (Gore Tex 5-0; W.L. Gore \& Associates, Inc Flagstaff, Arizona, USA). Patients were instructed to rinse with $0.2 \%$ chlorhexidine solution (Hibitan; Astra-Zeneca) and were prescribed with anti-inflammatory medications (Ponstan; Parke-Davis) and $2.25 \mathrm{~g}$ amoxiciline (Amoxicilline; Sandoz) per day for 7 days. Temporary removable partial dentures were adapted to avoid trauma to the surgical area. Suture removal was scheduled 7-10 days after surgery.

Three months later, abutment connection was performed, followed by the insertion of final fixed single-tooth reconstructions. Patients were then scheduled for a baseline examination and enrolled in an individual maintenance program.

\section{BASELINE AND FOLLOW-UP EXAMINATIONS}

Two weeks after insertion of final reconstructions, a baseline (BL) examination was performed. Further follow-up examinations took place at 6 months (6M), 1 year (FU-1) and 3 years (FU-3). All follow-up examinations were performed by a blinded examiner, not involved in the previous RCT and thereby unaware of the treatment the patients had received.

\section{OUTCOME MEASURES}

\section{Primary outcome measure: MUCOSAL thickNess}

The mucosal thickness was measured using an endodontic file (K-File 31/15, Dentsply Maillefer, York, USA). The file was inserted $1 \mathrm{~mm}$ apical of the mucosal margin on the buccal side of the implant crown. The change in mucosal thickness over time (BL to FU-3) was considered as primary outcome. Stability was considered as changes $<0.5 \mathrm{~mm}$ (Sapata et al., 2018).

\section{SECONDARY OUTCOME MEASURES}

\section{PROFILOMETRIC CHANGES OF THE PERI-IMPLANT TISSUES}

Impressions of the implant sites and the two neighbouring teeth were taken using an Asilicone impression material (President, Coltene/Whaledent, Alstätten, Switzerland). Casts were made out of dental stone and scanned to STL (stereolithography) files. The STL files were then imported into a digital imaging software program (SMOP, Swissmeda, Zurich, Switzerland). The ROI (region of interest) had a trapezoid shape and was defined as follows: the coronal border was $1 \mathrm{~mm}$ apical of the mucosal margin; the apical border was located at

This article is protected by copyright. All rights reserved 
the mucogingival junction; the mesial and distal borders were at a distance of $1 \mathrm{~mm}$ from the neighbouring teeth (Figure $1 \mathrm{~A}, \mathrm{~B}$ ). The ROI varied between patients due to inter-individual anatomical differences between the sites. Once the ROI was defined in the first assessment, it had the same dimension at all assessment time-points. The STL data of the baseline models were superimposed with the follow-up models (6M, FU-1 and FU-3) by using the best-fit algorithm on the surfaces of the surrounding structures. The software then measured the mean distance between the surfaces (representing the time-points: BL, 6M, FU-1, FU-3) within the ROI in $\mathrm{mm}$.

\section{CLINICAL AND PERIOdONTAL MEASUREMENTS}

The following measurements were performed at the implant sites and the two neighbouring teeth: probing depth (PD), the plaque index (PI) (Loe and Silness, 1963), bleeding on probing (BOP), the width of keratinized tissue (KT) at the buccal aspect. All measurements (except the width of KT) were assessed at 6 sites at each implant site and the two adjacent teeth.

\section{RADIOLOgIC EXAMINATION AND ASSESSMENT OF BONE LosS}

Marginal bone loss was recorded by measuring the first bone to implant contact (fBIC) at the mesial and distal aspect of each implant at BL and after 3 years. FBIC was measured on periapical radiographs taken with the long-cone paralleling technique and a software program (Image] 1.51; Wayne Rasband, National Institutes of Health, Bethesda, MD, USA). The implant length was used to calibrate the measurement. The reported fBIC length represents the average of the mesial and distal measurement.

This article is protected by copyright. All rights reserved 


\section{ESTHETICS}

The papilla fill was evaluated using the papilla index (Jemt, 1997). The papilla score was measured for each implant site and the contralateral tooth site on the mesial and distal aspect. The crown height was assessed by measuring the distance between the incisal edge and the most apical location of the mucosal margin on the buccal side. In addition, the Pink Esthetic Score (PES) (Furhauser et al., 2005) was recorded evaluating the peri-implant soft tissues and encompassing 7 parameters and scores from 0 (poorest) to 2 (best). The highest achievable score was 14 .

\section{PATIENT-REPORTED OUTCOME MEASURES (PROMS)}

PROMs were assessed at each follow-up time-point by patients filling out a standardized questionnaire (oral health impact profile-G14; OHIP-G14).

\section{RANDOMIZATION PROCEDURE, CONCEALMENT OF ALLOCATION AND OUTCOME ASSESSMENTS}

In order to guarantee balance in patients allocated to either group, block randomization was used. Allocation concealment was performed by a study monitor, preparing the assignments in opaque, sealed envelopes. Group allocation was revealed during surgery after preparation of the recipient site. Due to the nature of the treatment, only the outcome assessment procedure could be blinded. Follow-up examinations were performed by a blinded examiner not involved in the surgical phase of the study.

\section{Statistical analysis}

Mean, median, standard deviation and the quartiles Q1 and Q3 were used to describe the continuously scaled variables (expressed as median (Q1;Q3) later on) and counts and percentages for categorically scaled variables. Nonparametric statistical methods were applied. The differences of the medians between the treatment groups were evaluated with the Mann-Whitney and within a treatment group with the Wilcoxon signed rank test. The treatment-related differences of medians are expressed as Hodges-Lehmann-estimates incl. the 95\%-confidence intervals. The data were analyzed as intention-to-treat set (ITT: all randomized patients with post-baseline data). No relevant differences were found between the results in both analysis sets. The results for the primary objective are therefore presented as PP analysis set (ITT analysis is not generally conservative in non-inferiority trials). As this was a follow-up investigation of a previously performed randomized controlled

This article is protected by copyright. All rights reserved 
clinical trial, the sample size resulted out of the corresponding published study (Thoma et al., 2016). The original sample size was calculated based on a non-inferiority analysis.

This article is protected by copyright. All rights reserved 


\section{RESULTS}

VCMX was randomly applied to 10 patients (mean age $44.1 \pm 12.8$ years; 7 female and 3 males) whereas the remaining 10 patients were treated with a SCTG (mean age $43.4 \pm 18.8$ years, 6 female and 4 males). Table 1 displays an overview on patient demographics. A baseline examination was performed in all 20 patients between November 2012 and April 2015.

Out of the originally 20 patients entering the RCT, 17 attended the FU-3 examination between November 2015 and March 2018. Two patients (one for each group) died between FU-1 and FU-3. Another patient (group VCMX) relocated and did not attend any follow-up examination. The remaining 17 patients were included in the analysis (Fig. 2).

\section{Mucosal thickness}

The median mucosal thickness at baseline was $3.0 \mathrm{~mm}$ (Q1 first quartile: 3.0 ; Q3 third quartile: 4.0 ) in group VCMX and $3.0 \mathrm{~mm}(2.5 ; 3.0)$ in group SCTG (intergroup comparison: $\mathrm{p}$ $=0.128)$. The respective figures at FU-3 were $3.5 \mathrm{~mm}(3.0 ; 4.0)$ (VCMX) and $3.3 \mathrm{~mm}$ $(3.0 ; 5.5)$ (SCTG) (intergroup comparison: $p=0.901$ ). The median changes in mucosal thickness were $0.5 \mathrm{~mm}(-0.5 ; 1.3)$ in group $\operatorname{VCMX}(p=0.281)$. The respective numbers in group SCTG were $0.8 \mathrm{~mm}(0.0 ; 2.5)(p=0.047)$. Intergroup comparisons over time and at any time-point were not statistically significantly different (Table 2 ).

\section{Profilometric changes of the peri-implant tissues}

Between BL and FU-3 both groups demonstrated a significant median decrease in the soft tissue contour of $-0.2 \mathrm{~mm}(-0.5 ;-0.1)$ for $\operatorname{VCMX}(p=0.039)$ and $-0.1 \mathrm{~mm}(-0.8 ; 0.1)$ for SCTG respectively $(p=0.020)$. Between the two groups, no statistically significant differences were observed (Hodges-Lehmann estimation of difference: $-0.05, p=0.596)$. All data is displayed in Table 3 .

\section{Clinical and periodontal measurements}

The peri-implant tissues were healthy at $\mathrm{BL}$ as well as at FU-3. Changes over time were minimal except for PD in group SCTG with a median increase between BL and FU-3 of $0.50 \mathrm{~mm}(0.28 ; 0.67)(p=0.004)$. Differences between VCMX and SCTG sites were not statistically significant for any of the outcomes measure (PI, BOP, PD, KT) at any time-point ( $p>0.05$ ) (Appendix Table 1 A, B, C, D).

\section{RADiologic EXamination AND AsSessment of Bone Loss}

A statistically significant difference between treatment groups was observed at baseline for VCMX $0.3 \mathrm{~mm}(0.3 ; 0.6)$ vs. SCTG $-0.1 \mathrm{~mm}(-0.4 ; 0.2)$ (intergroup $\mathrm{p}=0.006)$ (Table 4). 
Although a higher marginal bone loss was observed for VCMX after 3 years vs. baseline $0.7 \mathrm{~mm}(-1.5 ;-0.1)(\mathrm{p}=0.016)$ compared to SCTG $-0.2 \mathrm{~mm}(-0.4 ;-0.0)(\mathrm{p}=0.012)$, the difference in change of $-0.679(95 \%-\mathrm{CI}:-1.36 ; 0.12 \mathrm{~mm})$ (Table 4 ) was not significant (intergroup $\mathrm{p}=0.163$ ).

\section{Esthetics}

Median PES scores were $9.0(9.0 ; 11.0)$ for VCMX and $8.5(6.0 ; 11.0)$ for SCTG at BL (intergroup $\mathrm{p}=0.444)$. At FU-3, PES scores amounted to $8.5(7.5 ; 11.0)$ for VCMX and 10 $(9.0 ; 10.0)$ for SCTG (intergroup $p=0.354$ ) (Appendix Table 2).

\section{Patient-reported outcome measures}

Median overall OHIP scores were 0 at $\mathrm{BL}$, at $6 \mathrm{M}$ and at FU-1. The respective numbers at FU3 , however, were significantly different between VCMX $0.5(0.0 ; 2.0)$ and SCTG $0.0(0.0 ; 0.0)$ (intergroup $\mathrm{p}=0.023$ ) (Appendix Table 3).

This article is protected by copyright. All rights reserved 


\section{Discussion}

The present RCT, comparing a soft tissue substitute to an autogenous connective tissue graft for gain of mucosal thickness at single implant sites demonstrated in both groups between baseline (crown insertion) and the 3-year follow-up: i) a slight increase in mucosal thickness; ii) a slight decrease of the buccal peri-implant tissue contour; iii) healthy peri-implant tissues and stable esthetics.

Soft tissue grafting procedures are frequently performed at implant sites for esthetic and biological reasons (Hammerle and Tarnow, 2018, Chen and Buser, 2014). Previous studies predominantly focused on the initial healing period following the grafting procedure and did not follow-up the patient population over time. Dental implants and the respective reconstructions demonstrate high long-term survival rates (Pjetursson et al., 2014, Jung et al., 2012). This does, however, not take into account any biological or esthetic outcomes. From the patient's and clinician's perspective, healthy and stable peri-implant tissues as well as aesthetics are essential. The goal of grafting procedures for gain of mucosal thickness is an increase in the buccal contour predominantly for aesthetic purposes as well as to maintain peri-implant health. Recent evidence suggests that implant sites having been grafted with soft tissue substitutes or autogenous grafts result in more stable marginal bone levels and superior peri-implant health (Linkevicius et al., 2015, Giannobile et al., 2018, Linkevicius et al., 2009, Thoma et al., 2018).

Methods to analyze soft tissues over time include transmucosal probing (endodontic instruments), ultrasonic devices and non-invasive profilometric and volumetric measurements based on casts or optical scans (Huber et al., 2018, Windisch et al., 2007, Fickl et al., 2009, Thoma et al., 2016, Eghbali et al., 2016). In the present study, the soft tissues were assessed by transmucosal probing and demonstrated an increase in mucosal thickness over time by $0.5 \mathrm{~mm}$ (VCMX) and $0.75 \mathrm{~mm}$ (SCTG) respectively. Absolute values of the mucosal thickness were $>3 \mathrm{~mm}$ at all time-points indicating that at implant sites, more soft tissue is present compared to natural teeth. In a recent RCT, a non-cross-linked collagen matrix (CM) was compared to a $1 \mathrm{~mm}$ thick, palatally harvested SCTG for gain of mucosal thickness at the time of abutment connection (Cairo et al., 2017). Transmucosal probing at 3 months yielded a thickness of $2.8 \mathrm{~mm}( \pm 0.7)$ for the CM group and $3.1 \mathrm{~mm}( \pm 0.5)$ for the SCTG group. At 6 months, a thickness of $3.0 \mathrm{~mm}( \pm 0.7)$ for the CM and $3.4 \mathrm{~mm}( \pm 0.6)$ for the SCTG group was measured. The study concluded that the use of an autogenous graft (SCTG) led to a higher increase of soft tissue thickness than CM $(0.3 \mathrm{~mm}$ higher mean values for SCTG). The obtained data for the final mucosal thickness is in line with the present study, revealing a mean soft tissue thickness of 2.94 (VCMX) and 2.95 (SCTG) at 6 months. The two studies, however, cannot be directly compared for gain of mucosal thickness, since in 
one study (Thoma et al., 2016), the soft tissue grafting procedure was performed prior to abutment connection, whereas in the second study, the mucosal thickness was increased in conjunction with abutment connection (Cairo et al., 2017). Interestingly, over time (up to 6 months), both studies revealed a stable mucosal thickness or even a slight gain.

Apart from measuring the mucosal thickness, changes of the buccal contour are a relevant outcome measure. This method is capable of measuring changes in the buccal contour between different time-points. Data over 3 years indicated an overall slight loss of the buccal contour between $0.2 \mathrm{~mm}$ (VCMX) and $0.13 \mathrm{~mm}$ (SCTG) in the present study. Changes of the buccal contour can be based on a loss of soft tissue, a loss of hard tissue or a combined loss of hard and soft tissue. At 3 years post-insertion of final reconstructions, the overall mucosal thickness in the present study was higher compared to all previous follow-up examinations. Without having cone-beam computed tomographies (CBCTs), one can only speculate that the increase in mucosal thickness (as assessed by transmucosal probing) was accompanied by ongoing changes of the hard tissues on the buccal side of the implants, since the buccal contour slightly decreased. In a RCT comparing facial augmentation by means of SCTG or GBR, measurements were performed by superimposition of CBCTs at three different timepoints (before surgery, 2 weeks after surgery and at the 1-year follow-up) (De Bruyckere et al., 2018). The mean gain of volume (mean absolute buccal soft tissue profile gain) after one year of healing time was similar: $0.94 \mathrm{~mm}$ in the GBR group and $0.81 \mathrm{~mm}$ in the SCTG group. In the SCTG group, a mean of $0.8 \mathrm{~mm}$ was lost, compared to a mean loss of $1.59 \mathrm{~mm}$ in the GBR group. The GBR group resulted in a higher absolute buccal soft tissue profile gain two weeks after surgery, due to limited dimensions of the SCTG and to significantly more oedema in the early stages of healing caused by higher invasiveness of the GBR procedure. This was followed by a significantly higher shrinkage rate in the GBR group.

Apart from improving aesthetics, soft tissue grafting procedures were also proposed to maintain peri-implant health and to minimize loss of marginal bone (Lin and Madi, 2019, Thoma et al., 2018). Without a control group (receiving no soft tissue grafting procedure), the beneficial effect of the surgical intervention can not be assessed in the present study. Based on clinical studies and systematic reviews, the soft tissue thickness and quality seems, however, to play an important role in maintaining or improving peri-implant health (Akcali et al., 2017, Sculean et al., 2019, Roccuzzo et al., 2017, Thoma et al., 2018, Furhauser et al., 2005). Whereas bleeding indices (a key factor to assess peri-implant health) do not appear to be influenced by a grafting procedure for gain of mucosal thickness, data from a systematic review indicated significantly less marginal bone loss over time and a borderline significance for marginal bone levels at the study endpoint (Thoma et al., 2018). These data

This article is protected by copyright. All rights reserved 
indicate the beneficial biological effect of grafting procedures for gain of mucosal thickness at implant sites. In the present study, peri-implant tissues were and remained healthy in both treatment groups. This was documented by stable BOP and PD values. Even though from a statistical point of view, in group SCTG, PD values increased significantly, the change of $0.5 \mathrm{~mm}$ might be clinically negligible.

One of the greatest benefits of using soft tissue substitutes is decreased patient morbidity. This was successfully documented in the previously published 3-month data RCT (Thoma et al., 2016) when PROMs were analyzed before and after the surgical procedure. Before the surgical procedure, the OHIP-14 scores amounted to 5.6 (VCMX) and 5.2 (SCTG). These values increased due to the surgical procedure (soft tissue grafting) to 6.1 (VCMX) and 7.6 (SCTG), demonstrating increased patient morbidity for the autogenous graft. Once final reconstructions were inserted, a new baseline examination took place. At that time-point and all subsequent follow-up time-points, OHIP-14 scores were calculated revealing values close to 0 at all time-points. It has previously been reported that OHIP scores assessed long after a successful therapy tend to reach values similar to the ones of healthy subject without any need of a therapy (John et al., 2004), thereby revealing an increased patient satisfaction. Interestingly at 3 years, the median OHIP score in group VCMX was significantly higher compared to all previous follow-up time-points and group SCTG. This was surprising since the tissues in the patient (responsible for the high values) were healthy and no biological, technical or esthetic problems had occurred. The respective patient, however, reported that the scores were due to personal issues and not related to the treatment.

\section{Conclusions}

Three years after insertion of final reconstructions, the comparison between VCMX and the gold standard (SCTG) demonstrated negligible differences and stable outcomes in terms of the buccal tissue contour, marginal bone levels and esthetics. Peri-implant tissue remained healthy throughout the study period. The mucosal thickness slightly increased in both groups and PROMs reached values similar to the ones of healthy subjects.

\section{CONFLICT OF INTEREST}

The authors report no conflict of interests related to the study or products involved.

\section{ORCID}

Daniel S. Thoma http://orcid.org/0000-0002-1764-7447

Thomas J. W. Gasser http://orcid.org/0000-0002-3161-6065

Ronald E. Jung https://orcid.org/0000-0003-2055-1320

Christoph H.F. Hämmerle https://orcid.org/0000-0002-8280-7347

This article is protected by copyright. All rights reserved 


\section{Table and figure legends}

Table 1: Patient demographics and p-values. SD = standard deviation; $\mathrm{Q} 1$ = first quartile; Q3 = third quartile; VCMX = volume-stable collagen matrix; SCTG = subepithelial connective tissue grafts; ${ }^{1}$ Mann-Whitney-U test

Table 2: Soft tissue thickness and p-values and change in soft tissue thickness and p-values. $\mathrm{SD}=$ standard deviation; $\mathrm{Q} 1$ = first quartile; $\mathrm{Q} 3$ = third quartile; VCMX = volume-stable collagen matrix; SCTG = subepithelial connective tissue graft; $\mathrm{BL}=$ baseline; $6 \mathrm{M}=$ follow-up at 6 months; FU-1 = follow-up at 1 year; FU-3 = follow-up at 3 years; MWU-test = MannWhitney-U test; ${ }^{1}$ non-parametric Wilcoxon test (changes vs. visit baseline); ${ }^{2}$ Mann-Whitney$\mathrm{U}$ test; ${ }^{3}$ Hodges-Lehmann estimate of the treatment-related difference including $95 \%$ confidence interval (CI).

Table 3: Profilometric changes and p-values. $\mathrm{SD}=$ standard deviation; $\mathrm{Q} 1$ = first quartile; Q3 = third quartile; VCMX = volume-stable collagen matrix; SCTG = subepithelial connective tissue graft; $\mathrm{BL}=$ baseline; $6 \mathrm{M}$ = follow-up at 6 months; FU-1 = follow-up at 1 year; FU-3 = follow-up at 3 years; ${ }^{1}$ non-parametric Wilcoxon test; ${ }^{2}$ Mann-Whitney- $U$ test; ${ }^{3}$ HodgesLehmann estimate of the treatment-related difference including $95 \%$ confidence interval (CI).

Table 4: Marginal bone levels at different time-points and $\mathrm{p}$-values. SD = standard deviation; $\mathrm{Q} 1$ = first quartile; $\mathrm{Q} 3$ = third quartile; $\mathrm{VCMX}=$ volume-stable collagen matrix; SCTG = subepithelial connective tissue graft; $\mathrm{BL}=$ baseline; $\mathrm{FU}-3=$ follow-up at 3 years; ${ }^{1}$ nonparametric Wilcoxon test; 2 Mann-Whitney-U test;

Figure 1A: A case of the VCMX-group: A) Clinical situation at baseline of the implant-born reconstruction in position $21 \mathrm{~B}$ ) Clinical situation at the 1-year follow-up C) Clinical situation at 3-year follow-up D) Cross-section through superimposed STL-files. Yellow line = baseline STL. Green Line = follow-up at 1-year STL. Red Line = follow-up at 3-year STL. E) View on 3-dimensional STL file at FU-3 with ROI. ROI = region of interest; STL = standard tessellation language; $\mathrm{VCMX}=$ volume-stable collagen matrix; SCTG = subepithelial connective tissue graft; $M G=$ margo mucosae.

Figure 1B: A case of the SCTG-group: A) Clinical situation at baseline of the implant born reconstruction 12 B) Clinical situation at 1-year follow-up C) Clinical situation at 3-year 
follow-up D) Cross-section through superimposed STL-files. Yellow line = baseline STL. Green Line = follow-up at 1-year STL. Red Line = follow-up at 3-year STL. E) View on 3dimensional STL file at FU-3 with ROI. ROI = region of interest; STL = standard tessellation language; $\mathrm{VCMX}=$ volume-stable collagen matrix; SCTG = subepithelial connective tissue graft; $M G=$ margo mucosae.

Figure 2: Consort flow-chart of study interventions. VCMX = volume-stable collagen matrix; SCTG = subepithelial connective tissue graft; PROMs = patient-reported outcome measures. 


\section{Appendix legends}

Appendix Table 1.

A. Bleeding on probing and $p$-values and change of bleeding on probing and $p$-values. $\mathrm{SD}=$ standard deviation; $\mathrm{Q} 1$ = first quartile; $\mathrm{Q} 3=$ third quartile; VCMX = volume-stable collagen matrix; SCTG = subepithelial connective tissue graft; $B L=$ baseline; $6 \mathrm{M}=$ follow-up at 6 months; FU-1 = follow-up at 1 year; FU-3 = follow-up at 3 years.

B. Plaque index and $p$-values (MWU-test) and change of plaque index and $p$-values. $\mathrm{SD}=$ standard deviation; $\mathrm{Q} 1=$ first quartile; $\mathrm{Q} 3=$ third quartile; VCMX = volume-stable collagen matrix; SCTG = subepithelial connective tissue graft; $\mathrm{BL}=$ baseline; $6 \mathrm{M}=$ follow-up at 6 months; FU-1 = follow-up at 1 year; FU-3 = follow-up at 3 years; ${ }^{1}$ non-parametric Wilcoxon test; ${ }^{2}$ Mann-Whitney-U test.

C. Probing depth and $\mathrm{p}$-values (MWU-test) and change of probing depth and $\mathrm{p}$-values. $\mathrm{SD}=$ standard deviation; $\mathrm{Q} 1$ = first quartile; $\mathrm{Q} 3=$ third quartile; $\mathrm{VCMX}=$ volume-stable collagen matrix; SCTG = subepithelial connective tissue graft; $\mathrm{BL}=$ baseline; $6 \mathrm{M}=$ follow-up at 6 months; FU-1 = follow-up at 1 year; FU-3 = follow-up at 3 years; ${ }^{1}$ non-parametric Wilcoxon test; ${ }^{2}$ Mann-Whitney-U test.

D. Width of keratinized tissue and p-values and change of width of keratinized tissue and pvalues.

$\mathrm{SD}=$ standard deviation; $\mathrm{Q} 1$ = first quartile; $\mathrm{Q} 3=$ third quartile; $\mathrm{VCMX}=$ volume-stable collagen matrix; SCTG = subepithelial connective tissue graft; $\mathrm{BL}=$ baseline; $6 \mathrm{M}=$ follow-up at 6 months; FU-1 = follow-up at 1 year; FU-3 = follow-up at 3 years; ${ }^{1}$ non-parametric Wilcoxon test; ${ }^{2}$ Mann-Whitney-U test.

Appendix Table 2. Pink esthetic score and p-values and change of pink esthetic score and $p$ values. $\mathrm{SD}=$ standard deviation; $\mathrm{Q} 1$ = first quartile; $\mathrm{Q} 3$ = third quartile; $\mathrm{VCMX}=$ volumestable collagen matrix; SCTG = subepithelial connective tissue graft; $\mathrm{BL}=$ baseline; $6 \mathrm{M}=$ follow-up at 6 months; FU-1 = follow-up at 1 year; FU-3 = follow-up at 3 years; ${ }^{1}$ nonparametric Wilcoxon test; ${ }^{2}$ Mann-Whitney-U test.

Appendix Table 3. OHIP-G14 score and p-values. SD = standard deviation; $Q 1$ = first quartile; $\mathrm{Q} 3$ = third quartile; $\mathrm{VCMX}=$ volume-stable collagen matrix; SCTG = subepithelial connective tissue graft; $\mathrm{BL}=$ baseline; $6 \mathrm{M}=$ follow-up at 6 months; FU-1 = follow-up at 1 year; FU-3 = follow-up at 3 years; ${ }^{1}$ Mann-Whitney-U test.

This article is protected by copyright. All rights reserved 


\section{Uncategorized References}

Akcali, A., Trullenque-Eriksson, A., Sun, C., Petrie, A., Nibali, L. \& Donos, N. (2017) What is the effect of soft tissue thickness on crestal bone loss around dental implants? A systematic review. Clinical Oral Implants Research 28, 1046-1053. doi:10.1111/clr.12916.

Bouri, A., Jr., Bissada, N., Al-Zahrani, M. S., Faddoul, F. \& Nouneh, I. (2008) Width of keratinized gingiva and the health status of the supporting tissues around dental implants. International Journal of Oral and Maxillofacial Implants 23, 323-326.

Cairo, F., Barbato, L., Tonelli, P., Batalocco, G., Pagavino, G. \& Nieri, M. (2017) Xenogeneic collagen matrix versus connective tissue graft for buccal soft tissue augmentation at implant site. A randomized, controlled clinical trial. Journal of Clinical Periodontology 44, 769-776. doi:10.1111/jcpe.12750.

Chen, S. T. \& Buser, D. (2014) Esthetic outcomes following immediate and early implant placement in the anterior maxilla--a systematic review. International Journal of Oral and Maxillofacial Implants 29 Suppl, 186-215. doi:10.11607/jomi.2014suppl.g3.3.

De Bruyckere, T., Eeckhout, C., Eghbali, A., Younes, F., Vandekerckhove, P., Cleymaet, R. \& Cosyn, J. (2018) A randomized controlled study comparing guided bone regeneration with connective tissue graft to re-establish convexity at the buccal aspect of single implants: A one-year CBCT analysis. Journal of Clinical Periodontology 45, 1375-1387. doi: $10.1111 /$ jcpe.13006.

Eghbali, A., De Bruyn, H., Cosyn, J., Kerckaert, I. \& Van Hoof, T. (2016) Ultrasonic Assessment of Mucosal Thickness around Implants: Validity, Reproducibility, and Stability of Connective Tissue Grafts at the Buccal Aspect. Clinical Implant Dentistry and Related Research 18, 51-61. doi:10.1111/cid.12245.

Fickl, S., Schneider, D., Zuhr, O., Hinze, M., Ender, A., Jung, R. E. \& Hurzeler, M. B. (2009) Dimensional changes of the ridge contour after socket preservation and buccal overbuilding: an animal study. Journal of Clinical Periodontology 36, 442-448. doi:10.1111/j.1600-051X.2009.01381.x.

Furhauser, R., Florescu, D., Benesch, T., Haas, R., Mailath, G. \& Watzek, G. (2005) Evaluation of soft tissue around single-tooth implant crowns: the pink esthetic score. Clinical Oral Implants Research 16, 639-644. doi:10.1111/j.1600-0501.2005.01193.x.

Giannobile, W. V., Jung, R. E., Schwarz, F. \& Groups of the 2nd Osteology Foundation Consensus, M. (2018) Evidence-based knowledge on the aesthetics and maintenance of peri-implant soft tissues: Osteology Foundation Consensus Report Part 1-Effects of soft tissue augmentation procedures on the maintenance of peri-implant soft tissue health. Clinical Oral Implants Research 29 Suppl 15, 7-10. doi:10.1111/clr.13110.

This article is protected by copyright. All rights reserved 
Hammerle, C. H. F. \& Tarnow, D. (2018) The etiology of hard- and soft-tissue deficiencies at dental implants: A narrative review. Journal of Periodontology 89 Suppl 1, S291-S303. doi:10.1002/JPER.16-0810.

Huber, S., Zeltner, M., Hammerle, C. H. F., Jung, R. E. \& Thoma, D. S. (2018) Noninterventional 1-year follow-up study of peri-implant soft tissues following previous soft tissue augmentation and crown insertion in single-tooth gaps. Journal of Clinical Periodontology 45, 504-512. doi:10.1111/jcpe.12865.

Jemt, T. (1997) Regeneration of gingival papillae after single-implant treatment. International Journal of Periodontics and Restorative Dentistry 17, 326-333.

John, M. T., Micheelis, W. \& Biffar, R. (2004) [Reference values in oral health-related quality of life for the abbreviated version of the Oral Health Impact Profile]. Schweizer Monatsschrift fur Zahnmedizin 114, 784-791.

Jung, R. E., Zembic, A., Pjetursson, B. E., Zwahlen, M. \& Thoma, D. S. (2012) Systematic review of the survival rate and the incidence of biological, technical, and aesthetic complications of single crowns on implants reported in longitudinal studies with a mean follow-up of 5 years. Clinical Oral Implants Research 23 Suppl 6, 2-21. doi:10.1111/j.1600-0501.2012.02547.x.

Lin, G. H. \& Madi, I. M. (2019) Soft-Tissue Conditions Around Dental Implants: A Literature Review. Implant Dentistry 28, 138-143. doi:10.1097/ID.0000000000000871.

Linkevicius, T., Apse, P., Grybauskas, S. \& Puisys, A. (2009) The influence of soft tissue thickness on crestal bone changes around implants: a 1-year prospective controlled clinical trial. International Journal of Oral and Maxillofacial Implants 24, 712-719.

Linkevicius, T., Puisys, A., Linkeviciene, L., Peciuliene, V. \& Schlee, M. (2015) Crestal Bone Stability around Implants with Horizontally Matching Connection after Soft Tissue Thickening: A Prospective Clinical Trial. Clinical Implant Dentistry and Related Research 17, 497-508. doi:10.1111/cid.12155.

Loe, H. \& Silness, J. (1963) Periodontal Disease in Pregnancy. I. Prevalence and Severity. Acta Odontologica Scandinavica 21, 533-551. doi:10.3109/00016356309011240.

Lorenzo, R., Garcia, V., Orsini, M., Martin, C. \& Sanz, M. (2012) Clinical efficacy of a xenogeneic collagen matrix in augmenting keratinized mucosa around implants: a randomized controlled prospective clinical trial. Clinical Oral Implants Research 23, 316-324. doi:10.1111/j.1600-0501.2011.02260.x.

Pjetursson, B. E., Asgeirsson, A. G., Zwahlen, M. \& Sailer, I. (2014) Improvements in implant dentistry over the last decade: comparison of survival and complication rates in older and newer publications. International Journal of Oral and Maxillofacial Implants 29 Suppl, 308-324. doi:10.11607/jomi.2014suppl.g5.2.

This article is protected by copyright. All rights reserved 
Roccuzzo, M., Savoini, M., Dalmasso, P. \& Ramieri, G. (2017) Long-term outcomes of implants placed after vertical alveolar ridge augmentation in partially edentulous patients: a 10-year prospective clinical study. Clinical Oral Implants Research 28, 1204-1210. doi:10.1111/clr.12941.

Sapata, V. M., Sanz-Martin, I., Hammerle, C. H. F., Cesar Neto, J. B., Jung, R. E. \& Thoma, D. S. (2018) Profilometric changes of peri-implant tissues over 5 years: A randomized controlled trial comparing a one- and two-piece implant system. Clinical Oral Implants Research 29, 864-872. doi:10.1111/clr.13308.

Schneider, D., Grunder, U., Ender, A., Hammerle, C. H. \& Jung, R. E. (2011) Volume gain and stability of peri-implant tissue following bone and soft tissue augmentation: 1year results from a prospective cohort study. Clinical Oral Implants Research 22, 2837. doi:10.1111/j.1600-0501.2010.01987.x.

Sculean, A., Romanos, G., Schwarz, F., Ramanauskaite, A., Keeve, P. L., Khoury, F., Koo, K. T. \& Cosgarea, R. (2019) Soft-Tissue Management as Part of the Surgical Treatment of Periimplantitis: A Narrative Review. Implant Dentistry 28, 210-216. doi:10.1097/ID.0000000000000870.

Thoma, D. S., Benic, G. I., Zwahlen, M., Hammerle, C. H. \& Jung, R. E. (2009) A systematic review assessing soft tissue augmentation techniques. Clinical Oral Implants Research 20 Suppl 4, 146-165. doi:10.1111/j.1600-0501.2009.01784.x.

Thoma, D. S., Buranawat, B., Hammerle, C. H., Held, U. \& Jung, R. E. (2014) Efficacy of soft tissue augmentation around dental implants and in partially edentulous areas: a systematic review. Journal of Clinical Periodontology 41 Suppl 15, S77-91. doi: $10.1111 /$ jcpe. 12220.

Thoma, D. S., Jung, R. E., Schneider, D., Cochran, D. L., Ender, A., Jones, A. A., Gorlach, C., Uebersax, L., Graf-Hausner, U. \& Hammerle, C. H. (2010) Soft tissue volume augmentation by the use of collagen-based matrices: a volumetric analysis. Journal of Clinical Periodontology 37, 659-666. doi:10.1111/j.1600-051X.2010.01581.x.

Thoma, D. S., Naenni, N., Figuero, E., Hammerle, C. H. F., Schwarz, F., Jung, R. E. \& SanzSanchez, I. (2018) Effects of soft tissue augmentation procedures on peri-implant health or disease: A systematic review and meta-analysis. Clinical Oral Implants Research 29 Suppl 15, 32-49. doi:10.1111/clr.13114.

Thoma, D. S., Zeltner, M., Hilbe, M., Hammerle, C. H., Husler, J. \& Jung, R. E. (2016) Randomized controlled clinical study evaluating effectiveness and safety of a volumestable collagen matrix compared to autogenous connective tissue grafts for soft tissue augmentation at implant sites. Journal of Clinical Periodontology 43, 874-885. doi: $10.1111 /$ jcpe. 12588 .

This article is protected by copyright. All rights reserved 
Windisch, S. I., Jung, R. E., Sailer, I., Studer, S. P., Ender, A. \& Hammerle, C. H. (2007) A new optical method to evaluate three-dimensional volume changes of alveolar contours: a methodological in vitro study. Clinical Oral Implants Research 18, 545551. doi:10.1111/j.1600-0501.2007.01382.x.

Wolff, J., Farre-Guasch, E., Sandor, G. K., Gibbs, S., Jager, D. J. \& Forouzanfar, T. (2016) Soft Tissue Augmentation Techniques and Materials Used in the Oral Cavity: An Overview. Implant Dentistry 25, 427-434. doi:10.1097/ID.0000000000000385.

Zeltner, M., Jung, R. E., Hammerle, C. H., Husler, J. \& Thoma, D. S. (2017) Randomized controlled clinical study comparing a volume-stable collagen matrix to autogenous connective tissue grafts for soft tissue augmentation at implant sites: linear volumetric soft tissue changes up to 3 months. Journal of Clinical Periodontology 44, 446-453. doi: $10.1111 /$ jcpe. 12697.

This article is protected by copyright. All rights reserved 
Table 1

\begin{tabular}{|c|c|c|c|c|}
\cline { 3 - 5 } \multicolumn{2}{c|}{} & VCMX & SCTG & p-value $^{1}$ \\
\hline Gender & $\mathrm{n}$ (female) & 7 & 6 & $\mathrm{p}=1.000$ \\
& $\mathrm{n}$ (male) & 3 & 4 & $\mathrm{p}=1.000$ \\
\hline Age & Mean \pm SD & $44.1 \pm 12.8$ & $43.4 \pm 18.7$ & \\
& Median & 46.0 & 47.5 & $\mathrm{p}=0.184$ \\
& Q1;Q3 & $39.0 ; 48.0$ & $23.0 ; 60.0$ & \\
\hline Cigarettes & Mean \pm SD & $0.0 \pm 0.0$ & $1.0 \pm 2.5$ & \\
\hline per day & Median & 0.0 & 0.0 & \\
& Q1;Q3 & $0.0 ; 0.0$ & $0.0 ; 0.0$ & \\
& & &
\end{tabular}


Table 2

\begin{tabular}{|c|c|c|c|c|}
\hline & & $\mathrm{VCMX}[\mathrm{mm}]$ & SCTG [mm] & p-value ${ }^{2}$ \\
\hline \multirow{4}{*}{$B L$} & $n$ & 9 & 10 & $p=0.128$ \\
\hline & Mean \pm SD & $3.2 \pm 0.8$ & $2.7 \pm 0.4$ & \\
\hline & Median & 3.0 & 3.0 & \\
\hline & Q1;Q3 & $3.0 ; 4.0$ & $2.5 ; 3.0$ & \\
\hline \multirow{4}{*}{$6 M$} & $\mathrm{~N}$ & 8 & 10 & $p=1.000$ \\
\hline & Mean \pm SD & $2.9 \pm 0.9$ & $3.0 \pm 0.9$ & \\
\hline & Median & 3.0 & 3.0 & \\
\hline & Q1;Q3 & $2.0 ; 3.8$ & $2.0 ; 3.5$ & \\
\hline \multirow{4}{*}{ FU-1 } & $\mathrm{n}$ & 9 & 10 & $p=0.900$ \\
\hline & Mean \pm SD & $2.8 \pm 0.7$ & $3.1 \pm 1.3$ & \\
\hline & Median & 3.0 & 2.8 & \\
\hline & Q1;Q3 & $2.0 ; 3.0$ & $2.0 ; 4.0$ & \\
\hline \multirow{5}{*}{ FU-3 } & $\mathrm{n}$ & 9 & 10 & \multirow[t]{5}{*}{$p=0.901$} \\
\hline & Mean \pm SD & $3.6 \pm 1.5$ & $3.8 \pm 1.5$ & \\
\hline & Median & 3.5 & 3.3 & \\
\hline & Q1;Q3 & $3.0 ; 4.0$ & $3.0 ; 5.5$ & \\
\hline & Diff. $[95 \%-C l]^{3}$ & \multicolumn{2}{|c|}{$0.0[-1.5 ; 1.0]$} & \\
\hline \multirow{5}{*}{$\mathrm{BL}$ to $6 \mathrm{M}$} & $\mathrm{n}$ & 8 & 10 & $p=0.318$ \\
\hline & Mean \pm SD & $-0.3 \pm 0.9$ & $0.3 \pm 1.0$ & \\
\hline & Median & 0.0 & 0.0 & \\
\hline & Q1;Q3 & $-0.5 ; 0.0$ & $0.0 ; 1.0$ & \\
\hline & $\mathrm{p}^{1}$ & 0.750 & 0.500 & \\
\hline \multirow{5}{*}{$\mathrm{BL}$ to $\mathrm{FU}-1$} & $\mathrm{n}$ & 8 & 10 & $p=0.243$ \\
\hline & Mean \pm SD & $-0.4 \pm 0.9$ & $0.4 \pm 1.4$ & \\
\hline & Median & -0.5 & 0.0 & \\
\hline & Q1;Q3 & $-1.0 ; 0.3$ & $-0.5 ; 1.0$ & \\
\hline & $\mathrm{p}^{1}$ & 0.231 & 0.563 & \\
\hline \multirow{6}{*}{$\begin{array}{c}\mathrm{FU}-1 \text { to } \\
\mathrm{FU}-3\end{array}$} & $\mathrm{n}$ & 8 & 10 & \multirow[t]{6}{*}{$p=0.303$} \\
\hline & Mean \pm SD & $0.44 \pm 1.1$ & $1.1 \pm 1.5$ & \\
\hline & Median & 0.5 & 0.8 & \\
\hline & Q1;Q3 & $-0.5 ; 1.25$ & $0.0 ; 2.5$ & \\
\hline & $\mathrm{p}^{1}$ & 0.281 & 0.047 & \\
\hline & Diff. $[95 \%-C l]^{3}$ & \multicolumn{2}{|c|}{$-1.0[-2.0 ; 1.0]$} & \\
\hline
\end{tabular}


Table 3

\begin{tabular}{|c|c|c|c|c|}
\hline & & VCMX $[\mathrm{mm}]$ & SCTG [mm] & p-value ${ }^{2}$ \\
\hline $\mathrm{BL}$ to $6 \mathrm{M}$ & $\begin{array}{c}\mathrm{n} \\
\text { Mean } \pm \mathrm{SD} \\
\text { Median } \\
\text { Q1;Q3 } \\
\mathrm{p}^{1}\end{array}$ & $\begin{array}{c}9 \\
-0.1 \pm 0.4 \\
0.0 \\
-0.2 ; 0.1 \\
0.574\end{array}$ & $\begin{array}{c}10 \\
-0.2 \pm 0.3 \\
-0.1 \\
-0.3 ; 0.0 \\
\mathbf{0 . 0 4 9}\end{array}$ & $p=0.462$ \\
\hline $\mathrm{BL}$ to $\mathrm{FU}-1$ & $\begin{array}{c}\mathrm{n} \\
\text { Mean } \pm \mathrm{SD} \\
\text { Median } \\
\mathrm{Q} 1 ; \mathrm{Q} 3 \\
\mathrm{p}^{1}\end{array}$ & $\begin{array}{c}9 \\
-0.2 \pm 0.5 \\
-0.1 \\
-0.2 ; 0.0 \\
0.301\end{array}$ & $\begin{array}{c}10 \\
-0.2 \pm 0.2 \\
-0.2 \\
-0.4 ;-0.1 \\
\mathbf{0 . 0 0 2}\end{array}$ & $p=0.369$ \\
\hline \multirow[t]{2}{*}{$\mathrm{BL}$ to $\mathrm{FU}-3$} & $\begin{array}{c}\mathrm{n} \\
\text { Mean } \pm \mathrm{SD} \\
\text { Median } \\
\mathrm{Q} 1 ; \mathrm{Q} 3 \\
\mathrm{p}^{1}\end{array}$ & $\begin{array}{c}8 \\
-0.3 \pm 0.4 \\
-0.2 \\
-0.5 ;-0.1 \\
0.039\end{array}$ & $\begin{array}{c}9 \\
-0.2 \pm 0.3 \\
-0.1 \\
-0.8 ; 0.1 \\
\mathbf{0 . 0 2 0}\end{array}$ & $p=0.596$ \\
\hline & Diff. $[95 \%-C l]^{3}$ & \multicolumn{2}{|c|}{$-0.05[-0.49 ; 0.2]$} & \\
\hline
\end{tabular}


Table 4

\begin{tabular}{|c|c|c|c|c|}
\hline & & VCMX [mm] & SCTG [mm] & p-value ${ }^{2}$ \\
\hline$B L$ & $\begin{array}{c}\mathrm{n} \\
\text { Mean } \pm \mathrm{SD} \\
\text { Median } \\
\text { Q1;Q3 }\end{array}$ & $\begin{array}{c}8 \\
0.4 \pm 0.5 \\
0.3 \\
0.3 ; 0.6\end{array}$ & $\begin{array}{c}9 \\
-0.1 \pm 0.3 \\
-0.1 \\
-0.4 ; 0.2\end{array}$ & $p=0.006$ \\
\hline FU-3 & $\begin{array}{c}\mathrm{n} \\
\text { Mean } \pm \mathrm{SD} \\
\text { Median } \\
\mathrm{Q} 1 ; \mathrm{Q} 3\end{array}$ & $\begin{array}{c}8 \\
-0.5 \pm 1.0 \\
-0.4 \\
0.5 ; 0.0\end{array}$ & $\begin{array}{c}9 \\
-0.4 \pm 0.3 \\
-0.4 \\
-0.6 ;-0.3\end{array}$ & $p=0.736$ \\
\hline $\mathrm{BL}$ to $\mathrm{FU}-3$ & $\begin{array}{c}n \\
\text { Mean } \pm \text { SD } \\
\text { Median }\end{array}$ & $\begin{array}{c}8 \\
-0.9 \pm 1.0 \\
-0.7\end{array}$ & $\begin{array}{c}9 \\
-0.3 \pm 0.3 \\
-0.2\end{array}$ & $p=0.163$ \\
\hline
\end{tabular}




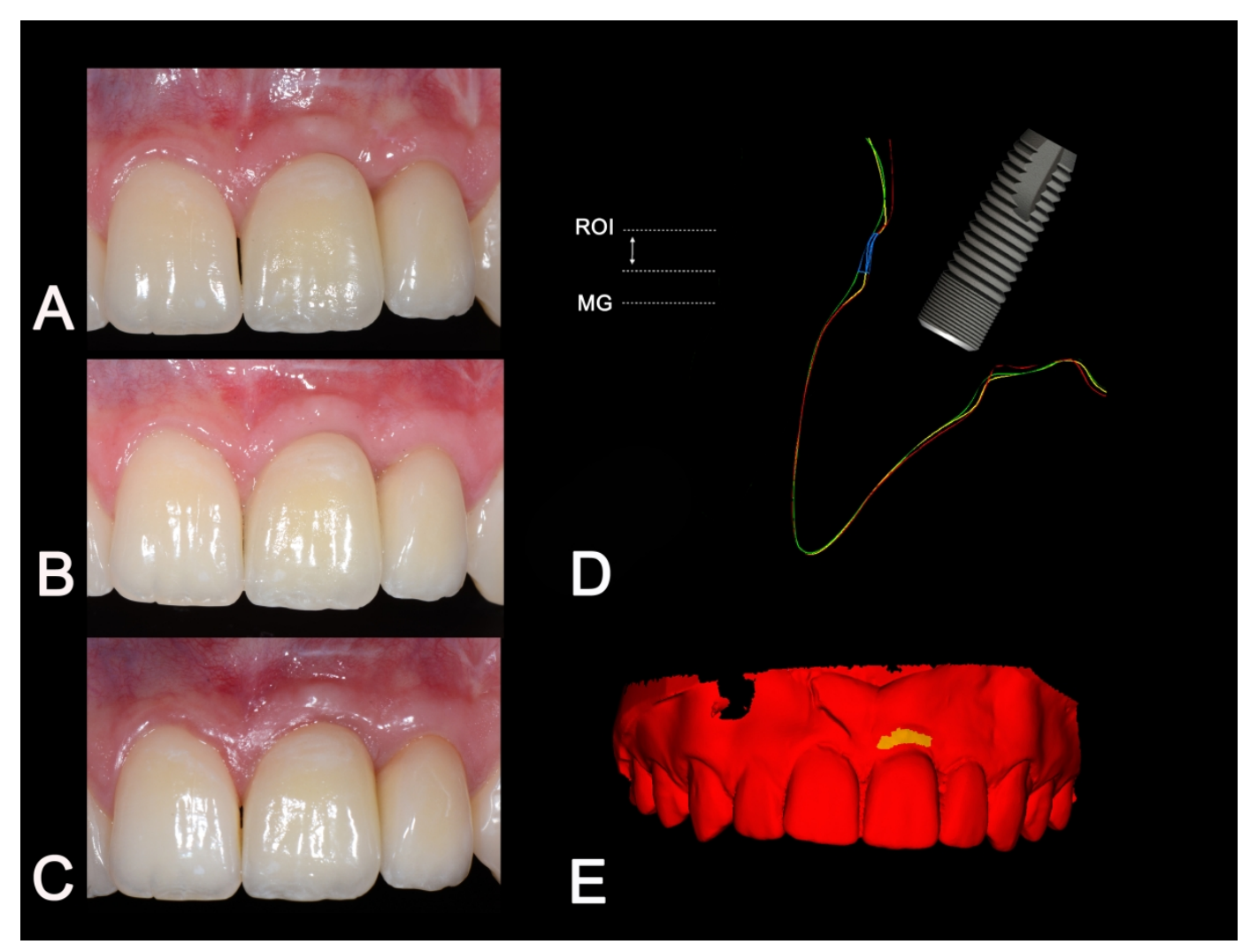

jcpe_13271_f1a.jpg 


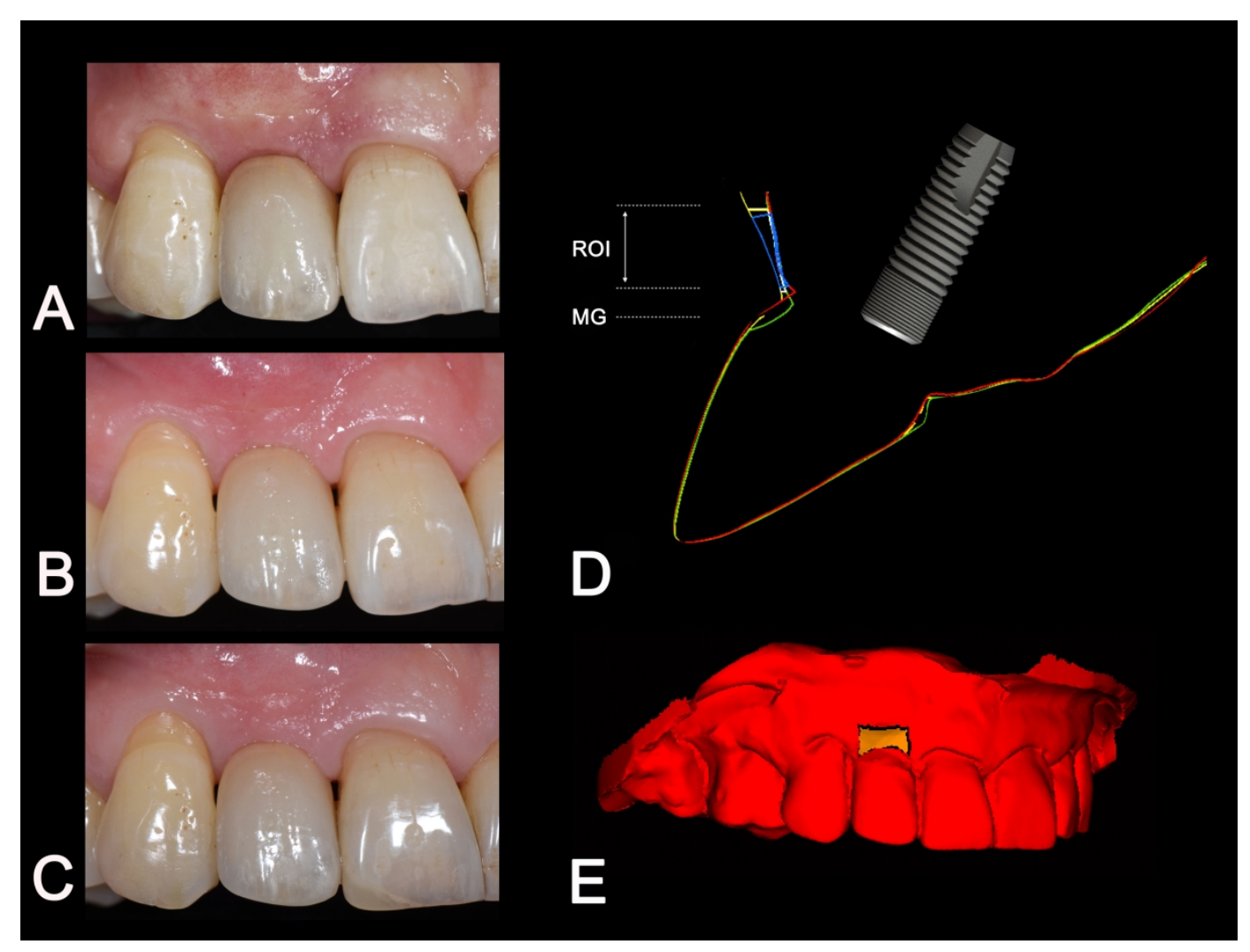

jcpe_13271_f1b.jpg 


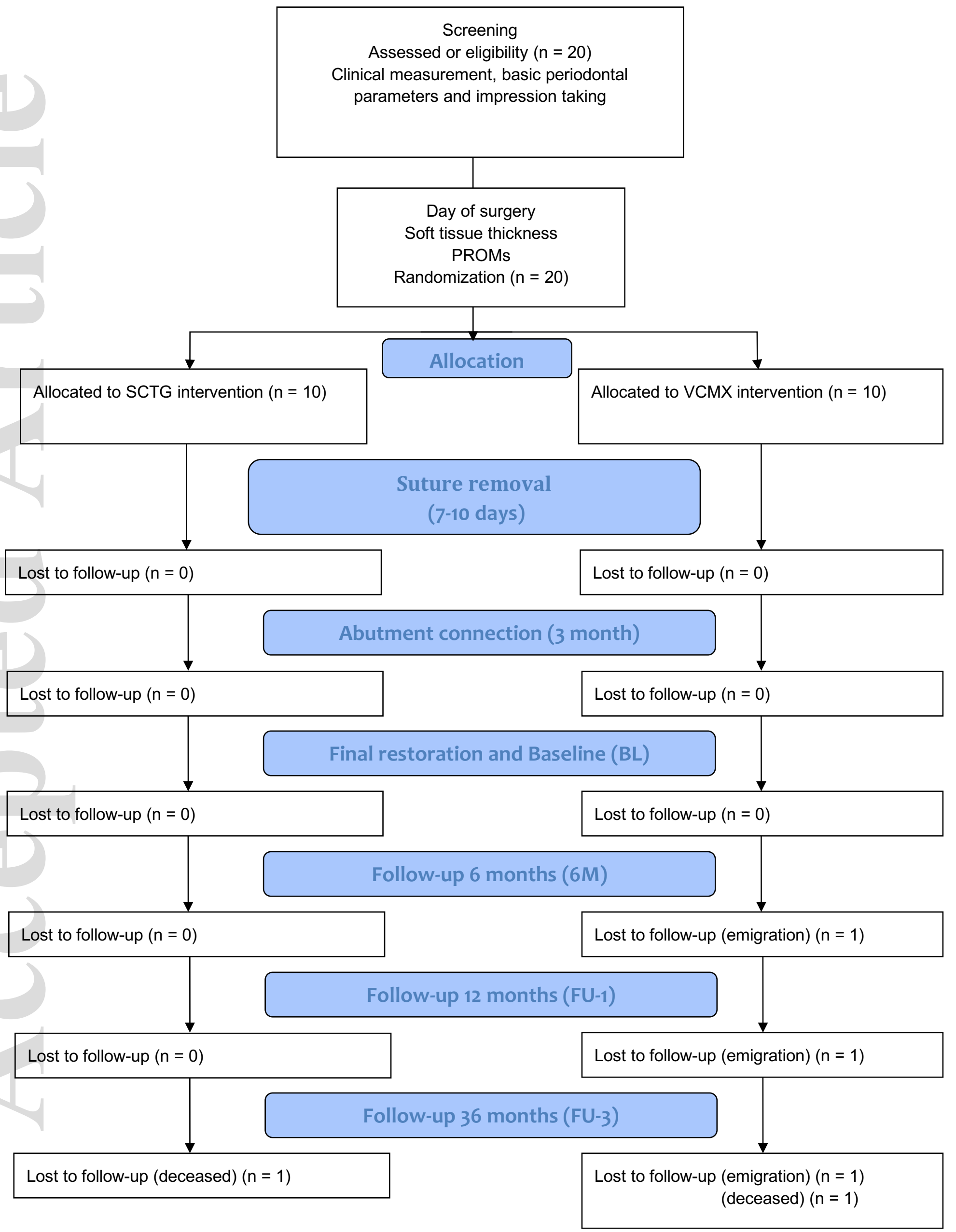

